\title{
PENGELOLAAN PERIKANAN SKALA KECIL DI PERAIRAN PESISIR KABUPATEN BANGKA DENGAN PENDEKATAN BIOEKONOMI
}

\section{Management of Small-Scale Fisheries in The Coastal Waters of Bangka Regency with Bioeconomic Approach}

\author{
*Yeyen Mardyani', Rahmat Kurnia', dan Luky Adrianto² \\ ${ }^{1}$ Bappeda Provinsi Kepulauan Bangka Belitung, Komplek Perkantoran Pemprov. \\ Jl. Pulau Belitung No.2 Kel. Air Itam, Pangkalpinang-33148, Indonesia \\ ${ }^{2}$ IPB University \\ Kampus IPB, JI. Raya Dramaga, Babakan, Kec. Dramaga, Bogor, Jawa Barat 16680, Indonesia \\ Diterima tanggal: 22 Januari 2020; Diterima setelah perbaikan: 22 Desember 2020; \\ Disetujui terbit: 28 Desember 2020
}

\begin{abstract}
ABSTRAK
Pengelolaan perikanan skala kecil di Kabupaten Bangka pada beberapa kurun waktu terakhir menunjukkan produktivitas yang semakin menurun. Hal ini disebabkan oleh pengelolaan ruang laut yang tidak hanya dimanfaatkan sebagai daerah penangkapan ikan, tetapi juga sebagai wilayah eksploitasi penambangan laut. Penelitian ini bertujuan untuk mengetahui status pemanfaatan perikanan skala kecil di perairan Kabupaten Bangka. Penelitian dilakukan dengan menggunakan data primer dan sekunder; analisis bioekonomi digunakan pada ketiga zona daerah penangkapan ikan (DPI) dengan memisahkan sumberdaya ikan pelagis dan demersal untuk melihat status pemanfaatan perikanan pada masing-masing zona. Ketiga zona daerah penangkapan ikan didasarkan pada kondisi eksisting menurut RZWP3K Provinsi Kepulauan Bangka Belitung, yaitu: Zona A (DPI dengan IUP), Zona A1 (DPI dengan IUP tanpa kegiatan), dan Zona B (DPI tanpa IUP). Hasil penelitian menunjukkan bahwa perikanan pelagis Zona A cenderung economical overfishing; sedangkan perikanan demersal sudah menunjukkan kondisi economical overfishing; Zona A1 berada pada kondisi underfishing; serta Zona B berada pada kondisi underfishing. Pemanfaatan perikanan Zona A dan A1 tidak mencapai $50 \%$ TAC; sedangkan pada Zona B hanya 15\% TAC. Agar pemanfaatan perikanan baik pelagis ataupun demersal dapat berkelanjutan baik secara ekologi maupun ekonomi, pengelolaan perikanan skala kecil di perairan Kabupaten Bangka perlu dilakukan pengelolaan input pada upaya tangkap yang berbeda-beda pada tiap zona serta pengelolaan ekologi dan ekosistem.
\end{abstract}

Kata Kunci: bioekonomi, daerah penangkapan ikan; perikanan skala kecil; perairan Bangka

\section{ABSTRACT}

Management of small-scale fisheries in Bangka Regency has recently shown decreased productivity. This is caused by the management of marine area which is not only used as a fishing ground, but also as an area of exploitation for off-shore mining. Based on these conditions, this study aims to determine the level of utilization of small-scale fisheries in the waters of Bangka Regency. This research uses primary and secondary data; bio-economic analysis was carried out in the three fishing ground zones by separating pelagic and demersal fish resources to see the utilization status of each zone. The three fishing ground zones are based on the existing fishing ground conditions according to RZWP3K Bangka Belitung Islands Province, namely: Zone A (fishing ground with IUP), Zone A1 (fishing ground with IUP without activities), and Zone B (fishing ground without IUP). The results showed that Pelagic Zone A fisheries tend to be economical, whereas demersal fisheries have shown economical overfishing; Zone $A 1$ is under fishing; Zone $B$ is under fishing. The utilization of fisheries in Zone $A$ and $A 1$ does not reach $50 \%$ TAC, while in Zone $B$ it is only $15 \%$ TAC. For the utilization of pelagic and demersal fisheries to be sustainable both ecologically and economically, the management of small-scale fisheries in Bangka Regency waters needs to carry out input management for different fishing efforts in each zone as well as ecological and ecosystem management.

Keywords: bio-economic; fishing ground; small-scale fisheries; Bangka Water 


\section{PENDAHULUAN}

Wilayah pesisir dan laut, terutama di negaranegara kepulauan atau pesisir (coastal nations) memberikan kontribusi yang besar terhadap pendapatan negara (Produk Domestik Bruto), terutama dari industri pesisir dan kelautan (Chua, 2006). Disatu sisi, pemanfaatan ruang laut yang bersifat open acces dimana setiap sektor yang memiliki keterkaitan dengan resources di wilayah pesisir dan laut (tambang, migas, perikanan, pariwisata, perhubungan) memiliki peluang dan posisi dalam memanfaatkan sumber daya yang ada (Dahuri, 2001; Dahuri 2015). Dalam pemanfaatan wilayah pesisir dan laut, sektor perikanan terutama perikanan skala kecil seringkali termajinalkan (Purcell \& Pomeroy, 2015), serta seringkali diabaikan dalam program perencanaan ekonomi nasional dan rencana alokasi perairan di tingkat lokal maupun nasional (Béné, Hersoug, \& Allison, 2010).

Upaya meningkatkan dan mengamankan kontribusi perikanan skala kecil di dalam sektor perikanan mengalami berbagai tantangan dan hambatan, seperti penangkapan sumber daya dan ancaman habitat dan ekosistem, perubahan sistem pengelolaan perikanan, perkembangan teknologi dan perubahan demografi. Di sisi lain, perikanan skala kecil juga mengalami berbagai tekanan baik konflik dengan perikanan skala besar (large-scale fishing operations), maupun kompetisi dengan sektor lain yang memiliki pengaruh politik dan ekonomi yang lebih kuat, seperti pariwisata, akuakultur, pertanian, energi, pertambangan, industri, dan pembangunan infrastruktur (FAO, 2015).

Pengelolaan wilayah pesisir dan laut mengacu pada konsep pembangunan berkelanjutan (sustainable development) yang menitikberatkan pada keseimbangan antara pertumbuhan ekonomi dan kualitas lingkungan serta sumber daya alam (Adrianto, 2006). Menurut Charles (2001), tujuan pengelolaan perikanan yang berkelanjutan adalah kondisi dimana pemanfaatan sumber daya pesisir dan laut dapat memberikan manfaat ekonomi yang tinggi (economic benefit), namun kelestarian tetap terjaga (sustainable ecological). Chaboud (1998) dalam Muawanah et al. (2017) menyebutkan bahwa bio-ekonomi adalah alat yang kuat untuk memahami dampak dari faktor eksogen, alami maupun ekonomi, pada dinamika perikanan dan untuk membantu pengambilan keputusan dalam pengelolaan perikanan.
Pemanfaatan wilayah pesisir dan laut di Kabupaten Bangka memiliki kompleksitas dari berbagai sektor, yaitu pertambangan, perikanan, dan pariwisata, sebagaimana tercantum dalam dokumen Rencana Zonasi Wilayah Pesisir dan Pulau-Pulau Kecil (RZWP3K) Provinsi Kepulauan Bangka Belitung mengenai pemanfaatan ruang wilayah pesisir dan laut di perairan Provinsi Kepulauan Bangka Belitung. Hampir 90\% pemanfaatan sumber daya perairan pesisir dan laut didominasi oleh peruntukan sektor pertambangan. Di sisi lain, wilayah pesisir terutama di perairan laut Kabupaten Bangka merupakan salah satu daerah penangkapan ikan yang paling potensial dan menjadi sentra perikanan skala kecil dengan hasil tangkapan didominasi oleh ikan pelagis dan demersal (BPS Kabupaten Bangka, 2018; DKP kabupaten Bangka, 2018; ESDM Provinsi Kepulauan Bangka Belitung, 2018).

Perikanan tangkap di Kabupaten Bangka berdasarkan data Perikanan Dinas Perikanan dan Kelautan (DKP) Provinsi Kepulauan Bangka Belitung, sampai dengan tahun 2018 didominasi oleh nelayan kecil dengan kapal motor tempel berukuran kurang dari 5 GT sejumlah 1.414 unit atau mencapai $56,86 \%$ dari total armada tangkap yang ada di perairan Kabupaten Bangka sebanyak 2.487 unit (Mardyani, Kurnia, \& Adrianto, 2019). Adapun produksi perikanan di Kabupaten Bangka terus mengalami fluktuasi dengan nilai produksi cenderung meningkat selama kurun waktu 5 tahun terakhir (2013-2018). Pada tahun 2018 produksi perikanan mencapai 30.954 ton atau senilai Rp745,563,943,933; sedangkan pada tahun 2013, produksi perikanan sebesar 25.034,7 ton dengan nilai produksi sebesar Rp469.163.785,90. Terdapat kenaikan nilai produksi perikanan sebesar $93,87 \%$ selama 5 tahun terakhir, yang berarti terjadi peningkatan nilai jual hasil perikanan yang cukup signifikan pada tahun 2018 (DKP Provinsi Kepulauan Bangka Belitung, 2019).

Permasalahan pengelolaan perikanan tangkap tidak hanya ada pada pola pengelolaan perikanan tangkap yang cenderung berorientasi pada produksi sehingga kelestarian sumber daya ikan tidak terjaga (Zulbainarni, 2016), tetapi juga degradasi dan pencemaran perairan yang berakibat pada penurunan produktivitas perikanan (Bidayani, 2014; Fauzi, 2010; Dahuri R, Rais J, Ginting SP, \& Sitepu, 2001). Pada perairan pesisir Kabupaten Bangka, permasalahan pengelolaan perikanan tangkap terutama disebabkan oleh pemanfaatan wilayah pesisir yang bersinggungan 
dengan pertambangan laut. Berdasarkan dokumen RZWP3K Provinsi Kepulauan Bangka Belitung, sebagian besar wilayah pesisir dan laut Kabupaten Bangka merupakan Izin Usaha Pertambangan (IUP) baik yang berasal dari PT Timah Tbk maupun perusahaan swasta (DKP Provinsi Kepulauan Bangka Belitung, 2019). Lebih dari 90\% IUP yang ada pada perairan Kabupaten Bangka adalah IUP swasta (ESDM Provinsi Kepulauan Bangka Belitung, 2018).

Pemanfaatan wilayah pesisir dan laut di yang didominasi oleh aktivitas pertambangan telah menimbulkan berbagai permasalahan, terutama terhadap aktivitas perikanan tangkap (Bidayani \& Kurniawan, 2020a; Bidayani, Kurniawan, Anggeraini, \& Aisyah, 2020; Manik, 2018; Nurtjahya \& Agustina, 2015; Ramadona et al., 2020). Pesisir sebagai sumber daya open access memiliki potensi konflik pemanfataan ruang (Bidayani \& Kurniawan, 2020b; Kim, 2009). Penelitian Sulista, Ibrahim, \& Pratama (2019) dan Ibrahim, Haryadi, \& Wahyudin (2018) menyatakan bahwa keberadaan IUP laut yang berdampingan dengan lokasi daerah penangkapan ikan menimbulkan konflik dengan nelayan setempat. Konflik kepentingan antara nelayan dan penambang adalah permasalahan utama bagi keberlanjutan kedua sektor ini (Ramadona et al., 2020). Menurut Agustinus (2018) dan KIARA (2013), dominasi pertambangan timah pada wilayah perairan menjadikan akses nelayan terhadap wilayah penangkapan ikan menjadi sulit akibat kapal-kapal timah beroperasi mulai dari pesisir sampai radius 2 mil sehingga nelayan melaut lebih jauh dengan waktu yang lebih lama (Mardyani et al., 2019). Nelayan lokal yang sepenuhnya bergantung pada ekosistem pesisir merupakan kelompok masyarakat pesisir yang terdampak langsung oleh aktifitas penambangan (Helmi \& Satria, 2012; Rosyida \& Sasaoka, 2018).

Pembangunan sektor perikanan diKabupaten Bangka harus memperhatikan keberlangsungan sumber daya perikanan sehingga kapasitas fungsionalnya dapat memberikan manfaat bagi kehidupan masyarakat secara berkelanjutan. Oleh karena itu, pengelolaan perikanan skala kecil di perairan Kabupaten Bangka memerlukan pendekatan khusus sebagai konsekuensi dari pemanfaatan wilayah perairan yang multi-sektor. Analisis keberlanjutan perikanan skala kecil di perairan Kabupaten Bangka melalui pendekatan bioekonomi dapat digunakan untuk melihat status pemanfaatan sumber daya perikanan yang ada pada wilayah pengelolaan perairan yang multisektor, sehingga dapat dirumuskan strategi pengelolaan perikanan yang berkelanjutan. Perikanan skala kecil yang menjadi objek penelitian sebagaimana definisi mengenai nelayan kecil yang tercantum pada Undang-undang Nomor 45 tahun 2009 tentang perubahan Undangundang Nomor 31 tahun 2004 tentang Perikanan. Batasan kawasan penelitian adalah Daerah Penangkapan Ikan (DPI) berdasarkan dokumen RZWP3K Provinsi Kepulauan Bangka Belitung yang difokuskan pada lokasi terkini DPI nelayan kecil yang berdampingan dengan lokasi Izin Usaha Pertambangan Timah (IUP) di perairan Kabupaten Bangka. Untuk mengetahui status pemanfaatan sumber daya ikan dan keberlanjutannya di perairan Kabupaten Bangka dengan status DPI yang berbeda-beda, maka DPI dibagi menjadi tiga zona, yaitu: (I) Zona A dengan IUP, yaitu DPI yang terdampak aktivitas pertambangan IUP; (II) Zona A1 dengan IUP tanpa kegiatan, yaitu DPI dengan IUP tanpa aktivitas pertambangan; dan (III) Zona B tanpa IUP (Gambar 1).

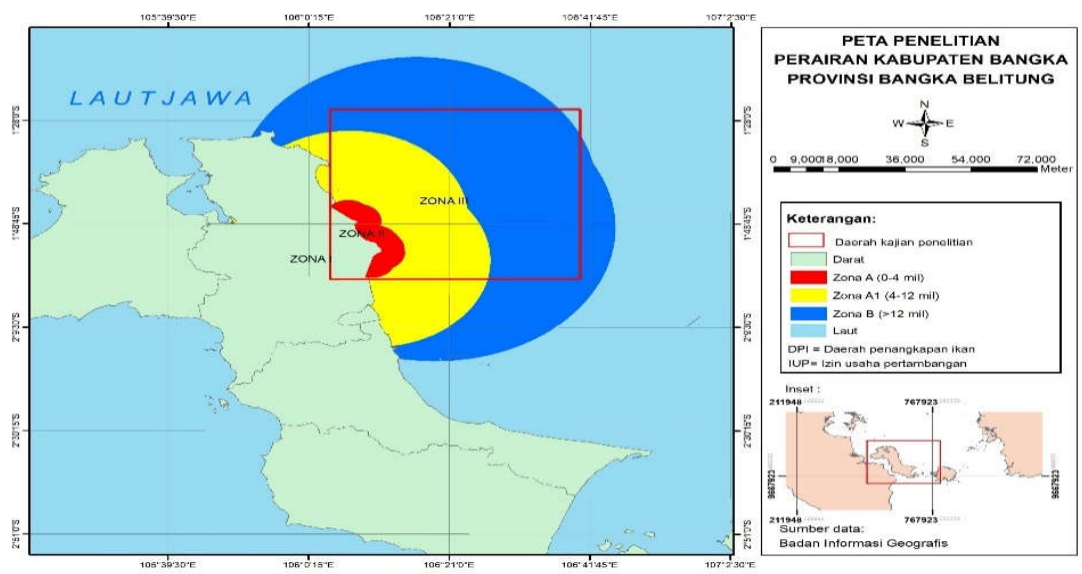

Gambar 1. Lokasi Penelitian di Wilayah Perairan Kabupaten Bangka. Figure 1. Research Location in Bangka Regency Water. 
Penelitian ini menggunakan data primer dan sekunder. Data primer meliputi biaya penangkapan (biaya operasional) dan harga ikan (hasil produksi). Pengumpulan data dilakukan dengan metode survei dan studi pustaka. Lokasi penelitian merupakan sentra nelayan kecil yang paling besar di Kabupaten Bangka yaitu Desa Matras dan Rebo dengan daerah penangkapan ikan tradisional yang paling luas di perairan timur Pulau Bangka. Responden merupakan nelayan lokal yang dikumpulkan melalui metode purposive sampling. Penetapan sampel didasarkan pada jumlah nelayan yang beroperasi di DPI tradisional yaitu Pantai Matras dan Rebo. Jumlah nelayan kecil di Desa Rebo sekitar 180 orang yang didominasi oleh nelayan bagan tancap dan pancing, dan Desa Matras sekitar 140 orang didominasi oleh nelayan jaring insang dan pancing. Ukuran sampel untuk nelayan skala kecil dihitung menurut Gay, Mills dan Airasian (2009) dalam Alwi (2012), untuk populasi yang relatif kecil minimal $20 \%$ dari total nelayan di tiap desa.

Data sekunder yang dikumpulkan meliputi data produksi dan upaya penangkapan (trip) yang diperoleh dari data statistik perikanan tangkap Dinas Kelautan dan Perikanan Provinsi Kepulauan Bangka Belitung dan Dinas Kelautan dan Perikanan Kabupaten Bangka. Data produksi merupakan data produksi per jenis ikan yang dipilih berdasarkan identifikasi hasil tangkapan dominan pada masing-masing zona DPI. Data produksi per jenis ikan tersebut kemudian dihitung secara kumulatif dan terpisah untuk masing-masing ikan pelagis dan demersal pada setiap zona DPI. Data upaya penangkapan adalah data effort berupa trip berdasarkan alat tangkap yang diidentifikasi dari alat tangkap dominan pada masing-masing zona DPI.

Analisis yang digunakan pada penelitian ini adalah analisis bioekonomi dengan pendekatan input. Pendekatan input digunakan dalam penelitian ini dikarenakan status pemanfaatan perikanan yang dilihat berdasarkan upaya penangkapan dari setiap jenis alat tangkap dominan yang digunakan pada masing-masing zona DPI.

\section{Analisis Bioekonomi}

Analisis bioekonomi perikanan skala kecil pada tiga zona pemanfaatan perikanan di wilayah pesisir Kabupaten Bangka menggunakan pendekatan input dengan model statis bioekonomi Gordon-Schaefer yang dibangun dari Model
Surplus Produksi (Fauzy \& Anna, 2005; Fauzi, 2010; Zulbainarni, 2016). Menurut Utami, Kusumastanto, Zulbainarni, \& Ayunda, (2020), pendekatan input lebih mengarah pada variabel yang mempengaruhi upaya tangkap (effort). Pemodelan bioekonomi secara statik dilakukan untuk mencari satu tingkat pengelolaan yang optimal, baik secara biologi (Maximum Sustainable Yield) maupun secara ekonomi (Maximum Economic Yield) didasarkan pada faktor input yaitu upaya yang tercurah dalam kegiatan penangkapan. Melalui suatu teknik pendugaan tertentu akan diperoleh suatu yield effort yang optimal sebagai variabel strategis bagi pengambil kebijakan dalam mengelola sumber daya perikanan secara lestari (Taufiq, 2007).

Data yang dikumpulkan adalah data biologi dan ekonomi. Data biologi berupa produksi ikan dan effort (trip berdasarkan alat tangkap) yang selanjutnya digunakan sebagai pendugaan parameter biologi yaitu laju pertumbuhan intrinsik (r), koefisien daya tangkap (q), dan daya dukung lingkungan perairan (K). Estimasi parameter biologi diperoleh dari persamaan fungsi produksi perikanan Gordon-Schaefer (1954) yang dikembangkan dari kurva pertumbuhan logistik (biologis) den gan memasukan faktor produksi atau input yaitu upaya tangkap (effort) sehingga diperoleh kondisi keseimbangan dimana produksi akan sama dengan pertumbuhan biologi (biological growth), melalui persamaan:

$$
q x E=r x\left(1-\frac{x}{K}\right)
$$

dimana $q$ adalah koefisien kemampuan alat tangkap, $E$ adalah upaya penangkapan (trip), $r$ adalah koefisien laju pertumbuhan alami ikan, $x$ adalah stok ikan (ton), dan $K$ adalah koefisien daya dukung lingkungan. Bila persamaan di atas diubah ke dalam nilai $x$ kemudian disubstitusikan ke dalam persamaan $h=q x E$, maka akan diperoleh fungsi produksi lestari dengan persamaan:

$$
h=q x E\left(1-\frac{q E}{r}\right)
$$

dengan melakukan regresi sederhana antara variabel upaya tangkap (effort) dan cacth per unit effort (CPUE), diperoleh estimasi parameter biologi melalui persamaan diatas. Dari persamaan fungsi produksi lestari tersebut, dengan memasukkan 
faktor ekonomi, yaitu (price, p) per satuan berat dan biaya dari input (cost, c), maka didapatkan keseimbangan bioekonomi statik Gordon Schaefer. Biaya yang digunakan adalah biaya penangkapan per tahun yang didapat dari rata-rata biaya operasional penangkapan dengan menggunakan persamaan Rahmat et al. (2013):

$$
c=\frac{\sum c_{i}}{n}
$$

dimana $c$ adalah biaya penangkapan ratarata (rupiah/trip), $c_{i}$ adalah biaya penangkapan nelayan ke-i, dan $n$ adalah jumlah nelayan (orang). Parameter harga dihitung dalam ukuran riil dengan cara menyesuaikannya dengan Indeks Harga Konsumen (IHK) agar pengaruh inflasi dapat dieliminir, yaitu berdasarkan persamaan menurut Fauzi dan Anna (2005):

$$
p_{r t}=\frac{p_{n t}}{I H K_{t}} \times 100
$$

dimana $p_{r t}$ adalah harga riil tahun ke-t; $p_{n t}$ adalah harga nominal tahun ke-t; dan $I H K_{t}$ adalah Indeks Harga Konsumen tahun ke-t.

Lebih lanjut, menurut Fauzi (2000), model Statik Bio-economic Gordon-Schaefer didasarkan pada beberapa asumsi yang meliputi: (1) Harga per satuan output (Rp per $\mathrm{kg}$ ) diasumsikan konstan atau kurva permintaan yang elastis sempurna; (2) Biaya per satuan unit (c) dianggap konstan; (3) Target spesies bersifat tunggal; (4) Struktur pasar bersifat kompetitif; dan (5) Hanya memperhitungkan faktor penangkapan. Untuk menduga nilai optimal pengelolaan perikanan skala kecil digunakan rezim pengelolaan sumber daya yang umum dipakai, yaitu rezim pengelolaan Maximum Sustainable Yield (MSY), Maximum Economic Yield (MEY), Open Access (OA) dengan menggunakan persamaan model bioekonomi statis (Tabel 1).

\section{BIOEKONOMI PERIKANAN SKALA KECIL PERAIRAN KABUPATEN BANGKA}

Sumber daya perikanan tangkap di perairan Kabupaten Bangka adalah bagian dari perairan Provinsi Kepulauan Bangka Belitung yang termasuk ke dalam Wilayah Pengelolaan Perikanan Negara Republik Indonesia (WPPNRI) 711. Berdasarkan Keputusan Menteri Kelautan dan Perikanan Nomor 50 KEPMEN-KP/2017 tentang Estimasi Potensi, Jumlah Tangkapan yang Diperbolehkan, dan Tingkat Pemanfaatan Sumber Daya Ikan di Wilayah Pengelolaan Perikanan Negara Republik Indonesia menunjukkan bahwa total potensi sumber daya ikan di WPPNRI 711 sebesar 767.126 ton yang terdiri dari ikan pelagis kecil $(43.05 \%)$, demersal $(24.23 \%)$, pelagis besar $(17.09 \%)$, ikan karang $(2.69 \%)$, udang penaeid $(8.13 \%)$, cumi-cumi $(3.06 \%)$, rajungan $(1.27 \%)$. kepiting $(0.30 \%)$, dan lobster $(0.19 \%)$. Di penelitian ini, perikanan skala kecil di perairan Bangka didasarkan pada zona jalur penangkapan ikan dan alat tangkap yang digunakan menurut Peraturan Menteri Kelautan dan Perikanan Nomor 71 Tahun 2016 (Tabel 2).

Karakteristik perikanan skala kecil di perairan Bangka berdasarkan kondisi nelayan pada sentra perikanan kecil di Desa Matras dan Rebo, khusus pada penelitian ini terbagi menjadi tiga zona

Tabel 1. Perhitungan Model Bioekonomi Statis pada Rezim Pengelolaan . Table 1. Estimation of a Static Bioeconomic Model on Management Regime.

\begin{tabular}{lccc}
\hline \multirow{2}{*}{ Variabel/Variable } & \multicolumn{3}{c}{ Rezim Pengelolaan/ Management Regimes } \\
\cline { 2 - 4 } Stok/Stock (x) & $\frac{K}{2}\left(1+\frac{c}{p q K}\right)$ & $\frac{K}{2}$ & OA \\
Produksi/Catch (h) & $\frac{r K}{4}\left(1+\frac{c}{p q K}\right)\left(1-\frac{c}{p q K}\right)$ & $\frac{r K}{4}$ & $\frac{r c}{p q}\left(1-\frac{c}{p q K}\right)$ \\
Upaya tangkap/Effort (E) & $\frac{r}{2 q}\left(1-\frac{c}{p q K}\right)$ & $\frac{r}{2 q}$ & $\frac{r}{q}\left(1-\frac{c}{p q K}\right)$
\end{tabular}

Sumber: Fauzi dan Anna (2005)/Source: Fauzi and Anna (2005) 
Tabel 2. Keragaan Perikanan Skala Kecil berdasarkan DPI di Kabupaten Bangka. Table 2. Small-Scale Fisheries Performance based on DPI in Bangka Regency.

\begin{tabular}{|c|c|c|c|}
\hline & Zona A/Zone A & Zona A1/Zone A1 & Zona B/Zone B \\
\hline $\begin{array}{l}\text { Daerah Penangkapan } \\
\text { Ikan/Fishing Ground* }\end{array}$ & $\begin{array}{l}\text { Jalur Penangkapan Ikan } \\
\text { IA (pantai - } 2 \text { mil) dan IB } \\
\text { (2-4 mil)/ Fishing Route } \\
\text { IA (coast - } 2 \text { miles) and IB } \\
\text { (2-4 miles) }\end{array}$ & $\begin{array}{l}\text { Jalur Penangkapan Ikan II (4-12 } \\
\text { mil)/ Fishing Route II (4-12 miles) }\end{array}$ & $\begin{array}{l}\text { Jalur Penangkapan Ikan } \\
\text { III (>12 mil-ZEE)/ Fishing } \\
\text { Route III (>12 miles-EEZ) }\end{array}$ \\
\hline $\begin{array}{l}\text { Kapal Tangkap/ } \\
\text { Fishing vessel ** }\end{array}$ & $\begin{array}{l}\text { Motor Tempel } 5 \text { - 9.8 PK/ } \\
\text { Outboard Motor } 5-9.8 \text { PK }\end{array}$ & $\begin{array}{l}\text { Motor Tempel } 9.8-15 \text { PK/ } \\
\text { Outboard Motor } 9.8 \text { - } 15 \text { PK }\end{array}$ & $\begin{array}{l}\text { Motor Tempel } 40-50 \text { PK/ } \\
\text { Outboard Motor } 40-50 \text { PK }\end{array}$ \\
\hline $\begin{array}{l}\text { Alat Tangkap/Fishing } \\
\text { Gear }^{* *}\end{array}$ & $\begin{array}{l}\text { Jaring insang hanyut } \\
\text { Drift gill net }\end{array}$ & Pancing ulur/ Hand line & $\begin{array}{l}\text { Bagan tancap/ Stationary } \\
\text { lift net }\end{array}$ \\
\hline $\begin{array}{l}\text { Hasil Tangkap } \\
\text { Dominan/Catch** }\end{array}$ & $\begin{array}{l}\text { Selar kuning (Selaroides } \\
\text { leptolepis), Kembung } \\
\text { (Rastrelliger sp.), Kurisi } \\
\text { (Nemipterus furcosus) }\end{array}$ & $\begin{array}{l}\text { Tenggiri (Scomberomorus sp.), } \\
\text { Alu-alu (Sphyraena barracuda), } \\
\text { Tetengkek (Megalaspis cordyla), } \\
\text { Kakap merah (Lutjanus sp.), } \\
\text { Kerapu karang (Epinephelus sp.), } \\
\text { Pari (Dasyatis sp.), Manyung } \\
\text { (Arius thalassinus) }\end{array}$ & $\begin{array}{l}\text { Tembang (Sardinella } \\
\text { gibbosa), Siro } \\
\text { (Amblygaster sirm), Teri } \\
\text { (Stolephorus sp.), Cumi- } \\
\text { cumi (Loligo spp.) }\end{array}$ \\
\hline $\begin{array}{r}\text { Sumber: * Peraturan Ment } \\
{ }^{* *} \text { Observasi da }\end{array}$ & Kelautan dan Perikanan Nom & r 71 Tahun 2016 & \\
\hline
\end{tabular}

daerah penangkapan ikan, yaitu Zona A, Zona A1, dan Zona B. Zona A merupakan wilayah DPI dengan jangkauan sampai 4 mil yang berbatasan langsung dengan wilayah IUP sampai dengan 4 mil. Rata-rata nelayan menggunakan perahu motor tempel dengan kapasitas 5-9,8 PK, dengan alat tangkap dominan adalah jaring insang hanyut yang digunakan untuk menangkap ikan pelagis kecil maupun demersal. Hasil tangkapan utama adalah ikan pelagis kecil yang didominasi oleh kembung dan selar kuning, dan ikan demersal yang umumnya didominasi oleh kurisi.

Zona A1 merupakan wilayah DPI antara 12-15 mil, rata-rata DPI termasuk ke dalam wilayah IUP yang belum terdapat aktivitas penambangan. Pada Zona A1, dominan nelayan menggunakan perahu motor tempel kapasitas 9.8-15 PK dengan alat tangkap berupa pancing ulur yang digunakan untuk menangkap tenggiri. Selain tenggiri, nelayan juga menangkap ikan pelagis lain seperti tetengkek dan alu-alu. Di luar musim penangkapan tenggiri yang hanya berlangsung selama 4 bulan (musim puncak), pada bulan-bulan lainnya nelayan menangkap ikan demersal dengan pancing ulur dengan hasil tangkapan didominasi oleh kakap merah, kerapu karang, kurisi, manyung, dan pari kembang.

Zona B merupakan wilayah DPI dari 12 mil sampai dengan 24 mil, tanpa adanya wilayah IUP.
Pada zona ini, nelayan rata-rata menggunakan perahu motor kapasitas 40-50 PK, dengan alat tangkap berupa bagan tancap dan hasil tangkapan utama adalah cumi-cumi dan sebagian ikan pelagis kecil yaitu tembang, teri, dan siro. Semenjak akhir tahun 2018, rata-rata bagan tancap dibangun di sekitar 20-24 mil perairan Rebo dan sekitarnya akibat semakin berkurangnya hasil tangkapan di lokasi sebelumnya yang berkisar antara 9-12 mil dikarenakan berkurangnya tutupan karang. Menurut Syari (2016), pada 4 lokasi terumbu karang di perairan Rebo sekitar 4,2-7,1 km atau 2,6-4,4 mil telah terjadi penurunan tutupan karang hidup dan peningkatan indeks mortalitas karang akibat terpengaruh tutupan lumpur yang diestimasi dari buangan tailing aktivitas penambangan timah laut oleh Kepal Keruk, KIP ataupun TI Apung.

Data produksi perikanan pelagis dan demersal dielaborasi dari data statistik perikanan time series dengan memilah data produksi berdasarkan jenis ikan dominan yang tertangkap sesuai Zona DPI masing-masing dan diakumulasikan tiap jenis ikan (Tabel 2). Secara umum, produksi ikan pelagis maupun demersal pada ketiga zona berfluktuatif setiap tahunnya. Beberapa jenis ikan mengalami peningkatan produksi seperti kurisi (Zona A) dan tenggiri (Zona A1). Sebaliknya, penurunan signifikan terjadi pada beberapa jenis ikan pelagis lain, yaitu selar kuning 
(Zona A), tembang, dan sio (Zona B). Sedangkan produksi ikan demersal, terutama ikan kakap merah, kerapu karang, dan pari kembang (Zona A1), termasuk cumi-cumi (Zona B) cenderung menurun. Adapun data upaya tangkap (effort) dielaborasi dari data statistik perikanan time series dengan memilah data trip berdasarkan alat tangkap sesuai zona DPI masing-masing. Effort pada masing-masing zona juga mengalami fluktuasi setiap tahun dimana pada Zona A dan Zona A1 cenderung menurun, sebaliknya pada Zona B cenderung meningkat (Tabel 3).
Upaya penangkapan (effort) dihitung berdasarkan trip alat tangkap yang digunakan pada masing-masing zona DPI (jaring insang hanyut, pancing ulur dan bagan tancap). Trip berdasarkan alat tangkap untuk masing-masing zona dihitung dari banyaknya bulan dalam musim penangkapan yang digunakan nelayan untuk melaut sehingga effort yang dikeluarkan untuk ikan pelagis dan demersal tidak sama. Pada Zona A, nelayan rata-rata menangkap ikan pelagis dengan jaring insang hanyut sebanyak 10 bulan, sedangkan demersal rata-rata 8 bulan. Nelayan pada Zona

Tabel 3. Produksi Ikan Pelagis dan Demersal pada Zona DPI (Ton), 2013-2018.

Table 3. Pelagic and Demersal Fish Production in The DPI Zones (Tons), 2013-2018.

\begin{tabular}{|c|c|c|c|c|c|c|c|c|}
\hline $\begin{array}{c}\text { DPI/ } \\
\text { Fishing } \\
\text { Ground }\end{array}$ & $\begin{array}{l}\text { Kondisi/ } \\
\text { Condition }\end{array}$ & 2013 & 2014 & 2015 & 2016 & 2017 & 2018 & $\begin{array}{l}\text { Rata-rata/ } \\
\text { Average }\end{array}$ \\
\hline \multirow[t]{6}{*}{$\begin{array}{l}\text { Zona A/ } \\
\text { Zone A }\end{array}$} & $\begin{array}{l}\text { Produksi ikan pelagis (ton)/ } \\
\text { Pelagic production (ton) }\end{array}$ & 2,688 & 2,717 & 1,608 & 1,981 & 2,456 & 1,150 & $2,100.06$ \\
\hline & $\begin{array}{l}\text { Upaya tangkap ikan pelagis (trip)/ } \\
\text { Pelagic Effort (trip) }\end{array}$ & 45,000 & 6,741 & 9,216 & 48,700 & 29,881 & 31,467 & $33,500.74$ \\
\hline & $\begin{array}{l}\text { Hasil tangkap per unit upaya } \\
\text { tangkap (ton/trip)/ CPUE (ton/trip) }\end{array}$ & 0.06 & 0.40 & 0.04 & 0.04 & 0.08 & 0.04 & 0.06 \\
\hline & $\begin{array}{l}\text { Produksi ikan demersal (ton)/ } \\
\text { Demersal Production (ton) }\end{array}$ & 1,397 & 1,424 & 241 & 451 & 1,164 & 1,815 & $1,081.93$ \\
\hline & $\begin{array}{l}\text { Upaya tangkap ikan demersal } \\
\text { (trip)/ Demersal Effort (trip) }\end{array}$ & 40,000 & 6,022 & 35,033 & 43,505 & 26,693 & 28,111 & $29,893.99$ \\
\hline & $\begin{array}{l}\text { Hasil tangkap per unit upaya } \\
\text { tangkap (ton/trip)/ CPUE (ton/trip) }\end{array}$ & 0.03 & 0.24 & 0.01 & 0.01 & 0.04 & 0.06 & 0.04 \\
\hline \multirow[t]{6}{*}{$\begin{array}{l}\text { Zona A1/ } \\
\text { Zone A1 }\end{array}$} & $\begin{array}{l}\text { Produksi ikan pelagis (ton)/ } \\
\text { Pelagic production (ton) }\end{array}$ & 2,394 & 2,440 & 896 & 921 & 2,930 & 3,168 & $2,124.82$ \\
\hline & $\begin{array}{l}\text { Upaya tangkap ikan pelagis (trip)/ } \\
\text { Pelagic Effort (trip) }\end{array}$ & 20,523 & 2,153 & 18,244 & 36,231 & 10,014 & 14,275 & $16,906.67$ \\
\hline & $\begin{array}{l}\text { Hasil tangkap per unit upaya } \\
\text { tangkap (ton/trip)/ CPUE (ton/trip) }\end{array}$ & 0.12 & 1.13 & 0.05 & 0.03 & 0.29 & 0.22 & 0.13 \\
\hline & $\begin{array}{l}\text { Produksi ikan demersal (ton)/ } \\
\text { Demersal Production (ton) }\end{array}$ & 8,131 & 8,543 & 1,260 & 2,203 & 7,538 & 3,722 & $5,232.76$ \\
\hline & $\begin{array}{l}\text { Upaya tangkap ikan demersal } \\
\text { (trip)/ Demersal Effort (trip) }\end{array}$ & 24,733 & 2,594 & 21,986 & 43,663 & 12,069 & 17,203 & $20,374.71$ \\
\hline & $\begin{array}{l}\text { Hasil tangkap per unit upaya } \\
\text { tangkap (ton/trip)/ CPUE (ton/trip) }\end{array}$ & 0.33 & 3.29 & 0.06 & 0.05 & 0.62 & 0.22 & 0.26 \\
\hline \multirow[t]{6}{*}{$\begin{array}{l}\text { Zona B/ } \\
\text { Zone B }\end{array}$} & $\begin{array}{l}\text { Produksi ikan pelagis (ton)/ } \\
\text { Pelagic production (ton) }\end{array}$ & 3,409 & 3,475 & 617 & 1,505 & 4,301 & 1,630 & $2,489.36$ \\
\hline & $\begin{array}{l}\text { Upaya tangkap ikan pelagis (trip)/ } \\
\text { Pelagic Effort (trip) }\end{array}$ & 6,622 & 576 & 8,881 & 11,491 & 45,846 & 56,394 & $21,635.01$ \\
\hline & $\begin{array}{l}\text { Hasil tangkap per unit upaya } \\
\text { tangkap (ton/trip)/ CPUE (ton/trip) }\end{array}$ & 0.51 & 6.03 & 0.07 & 0.13 & 0.09 & 0.03 & 0.12 \\
\hline & $\begin{array}{l}\text { Produksi ikan demersal (ton)/ } \\
\text { Demersal Production (ton) }\end{array}$ & 929 & 947 & 231 & 580 & 2,398 & 555 & 940.11 \\
\hline & $\begin{array}{l}\text { Upaya tangkap ikan demersal } \\
\text { (trip)/ Demersal Effort (trip) }\end{array}$ & 5,428 & 472 & 7,280 & 9,419 & 37,579 & 46,225 & $17,733.61$ \\
\hline & $\begin{array}{l}\text { Hasil tangkap per unit upaya } \\
\text { tangkap (ton/trip)/ CPUE (ton/trip) }\end{array}$ & 0.17 & 2.01 & 0.03 & 0.06 & 0.06 & 0.01 & 0.05 \\
\hline
\end{tabular}

Sumber: DKP Provinsi Kepulauan Bangka Belitung 2013-2018 (diolah)/

Sources: DKP of Bangka Belitung Archipelagos Province 2019 (data processed) 
A menggunakan pancing ulur untuk menangkap tenggiri selama musim puncak (rata-rata 4 bulan), dan pada bulan lainnya menangkap demersal (rata-rata 5 bulan). Adapun nelayan bagan pada Zona B, rata-rata menangkap cumi selama 6 bulan yang diselingi dengan tangkapan pelagis kecil rata-rata sekitar 7 bulan.

Selama kurun waktu 5 tahun terakhir, effort perikanan pelagis maupun demersal berbanding terbalik dengan hasil tangkapan yang diperoleh. Hal ini terlihat terutama pada Zona B, dimana effort semakin meningkat dengan laju produksi yang justru berkurang. Ini disebabkan oleh semakin bertambahnya jumlah Alat Penangkap Ikan (API) pada zona B yang didominasi oleh bagan tancap. Dalam waktu 5 tahun, jumlah bagan tancap bertambah sebanyak 65\% dari total 59 menjadi 169 unit. Sebaliknya pada Zona A dan Zona A1 jumlah API cenderung berkurang dari tahun ke tahun yaitu jaring insang hanyut sebanyak 476 dari 500 unit pada Zona A dan pancing sebanyak 355 dari 368 unit pada Zona A1, sehingga perbandingan effort yang dikeluarkan berbanding lurus dengan hasil tangkapan yang semakin berkurang.

Pengurangan jumlah API disebabkan oleh berpindahnya beberapa nelayan ke lokasi DPI yang lain atau beralihnya sebagian nelayan menjadi penambang inkonvensional yang dianggap lebih cepat memberikan keuntungan dibandingkan nelayan yang bergantung pada musim tangkap. Menurut Sulaiman, Zulkarnain, \& Fakhrurrozi (2015), aktivitas penambangan telah berdampak pada terjadinya peralihan mata pencaharian di kalangan komunitas warga dari semula sebagai nelayan ke buruh petambang $\mathrm{TI}$ apung secara perlahan-lahan.
Dari hasil rataan CPUE, Zona A1 menunjukkan nilai CPUE yang lebih besar dibandingkan Zona A dan Zona B, yang menandakan bahwa kegiatan perikanan pada Zona A1 memiliki produktivitas yang paling tinggi dibandingkan pada zona lainnya. Rata-rata CPUE pelagis pada Zona A lebih besar dari CPUE demersal dikarenakan musim penangkapan pelagis yang cenderung sepanjang tahun sedangkan demersal hanya pada musim puncak dan peralihan saja. Sebaliknya pada Zona A1, rata-rata CPUE pelagis lebih kecil dibandingkan CPUE demersal dikarenakan musim penangkapan pelagis terutama tenggiri hanya berlangsung sekitar 4 bulan (musim puncak), dan bulan lainnya dilakukan untuk menangkap ikan demersal dan pelagis lain. Sedangkan pada Zona B, rata-rata CPUE demersal jauh lebih besar dari pelagis dikarenakan ikan demersal,terutama cumi-cumi merupakan tangkapan utama dan pelagis sebagai sampingan.

Tahapan selanjutnya adalah melakukan estimasi parameter biologi. Pemanfaatan perikanan pada masing-masing Zona DPI bersifat gabungan atau multispesies, karenanya pendekatan yang digunakan dalam penelitian ini adalah menyamaratakan semua spesies. Menurut Zulbainarni (2016), pendekatan ini menggabungkan atau mencampurkan semua spesies sebagai stok spesies tunggal. Untuk menganalisisnya digunakan Model Surplus Produksi atau BiomassTotal Model Schaefer (1954). Estimasi parameter fungsi surplus produksi menggunakan regresi ordinary least square (OLS) untuk data time series upaya penangkapan (effort) dan CPUE yang menunjukkan nilai $\mathrm{R}^{2}$ dan $\mathrm{F}$ signifkansi untuk masing-masing zona DPI (Tabel 4).

Tabel 4. Tahapan analisis parameter biologi dengan menggunakan Model Surplus Produksi Schaefer.

Table 4. Biological Parameter Analysis Stages Using Schaefer's Surplus Production Model.

\begin{tabular}{|c|c|c|c|c|c|}
\hline \multirow{2}{*}{$\begin{array}{c}\text { DPI/ } \\
\text { Fishing Ground }\end{array}$} & \multirow{2}{*}{$\begin{array}{l}\text { Jenis Ikan/ } \\
\text { Type of fish }\end{array}$} & \multicolumn{2}{|c|}{ Koefisien/Coefficient } & \multirow{2}{*}{$\mathbf{R}^{2}$} & \multirow{2}{*}{ F significant } \\
\hline & & $\alpha$ & $\beta$ & & \\
\hline \multirow[t]{2}{*}{ Zona A/Zone A } & Pelagis/Pelagic & 0.3959109 & $(0.0000085)$ & 0.7866054 & 0.0184616 \\
\hline & Demersal/Demersal & 0.2450582 & $(0.0000060)$ & 0.8660829 & 0.0070502 \\
\hline \multirow[t]{2}{*}{ Zona A1/Zone A1 } & Pelagis/Pelagic & 0.7760975 & $(0.0000278)$ & 0.5840951 & 0.0768089 \\
\hline & Demersal/Demersal & 0.7019918 & $(0.0000158)$ & 0.5555576 & 0.0890084 \\
\hline \multirow[t]{2}{*}{ Zona B/Zone B } & Pelagis/Pelagic & 2.2055453 & $(0.0000490)$ & 0.2273008 & 0.3390430 \\
\hline & Demersal/Demersal & 0.7390081 & $0.0000196)$ & 0.2243804 & 0.3426111 \\
\hline
\end{tabular}


Berdasarkan Tabel 4, terlihat bahwa hubungan antara hasil tangkapan per unit upaya tangkap (CPUE) dan upaya tangkap (effort) dalam keseimbangan adalah linier. Selanjutnya, dari pemecahan hasil Tabel 4 dihitung nilai parameter biologi berdasarkan pada jenis ikan pelagis dan demersal untuk setiap zona DPI yang meliputi tingkat pertumbuhan intrinsik ( $r$ ), koefisien daya tangkap (q), dan daya dukung lingkungan perairan (K) (Tabel 5).

Hasil estimasi parameter biologi menunjukkan nilai intrinsic growth rate $(r)$ pada Zona A $(0,13)$ lebih kecil dibandingkan Zona A1 $(0,27)$ dan Zona B $(0,26)$. Adapun jenis ikan demersal pada Zona A1 $(0,50)$ lebih besar dibandingkan Zona lainnya $(0,13)$. Hal ini menandakan tingkat pertumbuhan alami pada jenis ikan demersal lebih cepat dibandingkan jenis ikan lainnya pada Zona lain. Nilai koefisien daya tangkap (q) pada demersal Zona A1 (0,00001049 ton/trip) juga menunjukkan tingkat efisiensi teknis dari kegiatan penangkapan jenis ikan demersal pada zona tersebut lebih tinggi dibandingkan jenis ikan lainnya pada Zona lain. Untuk daya dukung lingkungan perairan $(\mathrm{K})$, perikanan pelagis pada Zona B (558.821,49 ton/tahun) memiliki daya dukung yang lebih besar dibandingkan daya dukung perikanan pada Zona A dan A1. Kondisi ini menggambarkan bahwa daya dukung perairan pada Zona B dalam mendukung produksi ikan baik pelagis maupun demersal jauh lebih baik dari Zona A dan A1 yang berada pada kawasan IUP

Jika dibandingkan dengan hasil penelitian Bidayani (2014) pada perairan pesisir Tanjung Ular, Kabupaten Bangka Barat (1998-2008) menunjukkan nilai koefisien pertumbuhan alami (r) ikan pelagis kecil sebesar 0,18 dan ikan demersal sebesar 0,61. Koefisien alat tangkap (q) ikan pelagis sebesar 0,000114 dan ikan demersal sebesar 0,000218. sedangkan nilai daya dukung lingkugnan (K) pelagis sebesar 67.306,26 dan demersal sebesar 20.999,87. Hal ini menandakan bahwa rata-rata nilai $r$, pada perairan Kabupaten Bangka dan Kabupaten Bangka Barat berada pada kisaran yang sama, dan nilai q pada perairan Bangka yang lebih kecil, namun nilai $\mathrm{K}$ yang lebih besar dibandingkan pada perairan Bangka Barat. Menurut Bidayani (2014), hal ini dikarenakan sejak tahun 1998, aktivitas penambangan timah inkonvensional $(\mathrm{TI})$ telah mengakibatkan kerusakan pada pesisir Tanjung Ular, Bangka Barat.

Estimasi parameter ekonomimencakup harga per $\mathrm{kg}$ atau per ton dan biaya yang dikeluarkan untuk satu kali melaut (cost per unit effort). Nilai harga merupakan nilai rataan dari total jenis ikan baik pelagis dan demersal yang didapat dari data cross section dan series. Harga yang digunakan adalah harga riil yang dibagi dengan Indeks Harga Konsumen (IHK) untuk mengeliminir pengaruh inflasi, sedangkan biaya yang digunakan adalah biaya yang dikeluarkan dari total biaya per tahun per trip untuk masing-masing produksi ikan pelagis dan demersal per unit alat tangkap pada masingmasing zona. Dalam kajian bioekonomi GordonSchaefer, biaya penangkapan didasarkan pada asumsi bahwa hanya faktor penangkapan yang diperhitungkan dan dianggap konstan, sehingga dalam penelitian ini biaya penangkapan adalah biaya per trip. Nilai harga dan biaya disajikan pada Tabel 6.

Harga rata-rata ikan pelagis dan demersal pada masing-masing zona bergantung pada jenis ikan dominan yang tertangkap. Zona A1 memiliki nilai harga pelagis paling tinggi dikarenakan dominan ikan yang tertangkap adalah tenggiri yang memiliki harga rata-rata sekitar Rp52.500/kg, sedangkan pada zona lainnya adalah jenis pelagis kecil dengan harga yang rendah seperti selar kuning dengan kisaran harga Rp17.500/kg.

Tabel 5. Parameter Biologi Perikanan Pelagis dan Demersal pada Zona DPI.

Table 5. Biological Parameters of Pelagic and Demersal Fisheries in the DPI Zones.

\begin{tabular}{lllrr}
\hline $\begin{array}{c}\text { DPI/ } \\
\text { Fishing Ground }\end{array}$ & \multicolumn{1}{c}{$\begin{array}{c}\text { Jenis Ikan/ } \\
\text { Type of fish }\end{array}$} & $\boldsymbol{R}$ & $\mathbf{q}$ & K (ton) \\
\hline Zona A/Zone A & Pelagis/Pelagic & 0.13 & 0.00000189 & $209,468.55$ \\
& Demersal/Demersal & 0.13 & 0.00000271 & $90,267.07$ \\
Zona A1/Zone A1 & Pelagis/Pelagic & 0.27 & 0.00000694 & $111,837.57$ \\
& Demersal/Demersal & 0.50 & 0.00001049 & $197,569.38$ \\
Zona B/Zone B & Pelagis/Pelagic & 0.26 & 0.00000395 & $558,821.49$ \\
& Demersal/Demersal & 0.13 & 0.00000239 & $308,926.37$ \\
\hline
\end{tabular}


Tabel 6. Parameter Ekonomi Perikanan Pelagis dan Demersal pada Zona DPI. Table 6. Economic Parameters of Pelagic and Demersal Fisheries in DPI Zones.

\begin{tabular}{clcc}
\hline $\begin{array}{c}\text { DPI/ } \\
\text { Fishing Ground }\end{array}$ & \multicolumn{1}{c}{$\begin{array}{c}\text { Jenis Ikan/ } \\
\text { Type of fish }\end{array}$} & $\begin{array}{c}\text { Harga Rata-rata/ } \\
\text { Average of Price Per Ton of } \\
\text { Biomass (Rp juta/ton) }\end{array}$ & $\begin{array}{c}\text { Biaya Rata-rata/ } \\
\text { Average of Cost Per Unit } \\
\text { Effort (Rp juta/trip) }\end{array}$ \\
\hline Zona A/Zone A & Pelagis/Pelagic & 14,559 & 0.141 \\
\multirow{2}{*}{ Zona A1/Zone A1 } & Demersal/Demersal & 18,048 & 0.141 \\
& Pelagis/Pelagic & 21,243 & 0.215 \\
Zona B/Zone B & Demersal/Demersal & 19,913 & 0.215 \\
& Pelagis/Pelagic & 5,736 & 1.002 \\
& Demersal/Demersal & 33,029 & 1.300 \\
\hline
\end{tabular}

Sedangkan harga demersal yang paling tinggi berada pada zona B karena dominan yang tertangkap adalah cumi-cumi dengan harga rata-rata Rp60.000/kg. Biaya melaut (cost) yang dikeluarkan per trip untuk ketiga zona DPI yang menunjukkan nilai yang semakin meningkat dari Zona A sampai Zona B menunjukkan bahwa semakin jauh lokasi DPI, maka cost akan semakin bertambah.

Analisis bioekonomi yang dilakukan pada tiga zona menurut jenis ikan pelagis dan demersal menggunakan prinsip kehati-hatian (Charles, 2001) untuk mengetahui posisi effort dan produksi aktual berada pada kondisi efisien atau tidak, dimana basis dalam mengukur efisiensi menggunakan pendekatan laju penangkapan ikan maksimum yang diperbolehkan (Total Allowable Catch) yaitu 80\% MEY (Maximum Economic Yield). Hal ini didasari bahwa MEY merupakan alat ukur yang lebih sesuai dikarenakan tidak hanya parameter biologi yang dijadikan acuan, tetapi juga parameter ekonomi, dimana keseimbangan antara keberlanjutan biologi dan maksimalisasi produksi dapat mempertahankan keberlanjutan perikanan (Diop et al., 2018; Mota, 2020). Total Allowable Catch (TAC) merupakan kontrol terhadap aktivitas penangkapan agar eksploitasi sumber daya ikan dapat ditekan. Tekanan terhadap sumber daya ikan yang berlebihan pada satu area dapat menimbulkan gejala overfishing. Gejala overfishing dapat terjadi secara biologi, maupun ekonomi. Menurut Zulbainarni (2016), Hesselgrave, Kruse, \& Sheeran (2011), dan Pauly (1987), biological overfishing dapat terjadi ketika penangkapan melebihi kapasitas stok atau sumber daya sehingga kemampuan sumber daya untuk memproduksi pada tingkat Maximum Sustainable Yield menurun, sedangkan economic overfishing terjadi ketika pemanfaatan sumber daya perikanan yang seharusnya dapat menghasilkan rente ekonomi yang positif, justru menghasilkan rente negatif karena effort yang berlebih.

Hasil analisis bioekonomi pada ketiga zona menunjukkan kondisi pemanfaatan yang berbeda-beda berdasarkan kondisi aktual rata-rata ikan pelagis dan demersal masing-masing zona (Tabel 7).

Tabel 7. Hasil Analisis Bioekonomi Ikan Pelagis dan Demersal pada Zona DPI. Table 7. Results of Pelagic and Demersal Bio-Economic Analysis in The DPI Zones.

\begin{tabular}{|c|c|c|c|c|c|c|}
\hline \multirow{2}{*}{$\begin{array}{l}\text { Variabel/ } \\
\text { Variable }\end{array}$} & \multicolumn{2}{|c|}{ Zona A/Zone A } & \multicolumn{2}{|c|}{ Zona A1/Zone A1 } & \multicolumn{2}{|c|}{ Zona B/Zone B } \\
\hline & $\begin{array}{l}\text { Pelagis/ } \\
\text { Pelagic }\end{array}$ & $\begin{array}{l}\text { Demersal/ } \\
\text { Demersal }\end{array}$ & $\begin{array}{l}\text { Pelagis/ } \\
\text { Pelagic }\end{array}$ & $\begin{array}{l}\text { Demersal/ } \\
\text { Demersal }\end{array}$ & $\begin{array}{l}\text { Pelagis/ } \\
\text { Pelagic }\end{array}$ & $\begin{array}{l}\text { Demersal/ } \\
\text { Demersal }\end{array}$ \\
\hline$x M S Y$ (ton) & $104,734.27$ & $98,784.69$ & $55,918.78$ & $45,133.53$ & $279,410.75$ & $154,463.18$ \\
\hline$x M E Y$ (ton) & $107,295.92$ & $99,299.51$ & $56,648.45$ & $46,572.17$ & $301,533.11$ & $162,689.62$ \\
\hline$x O A$ (ton) & $5,123.29$ & $1,029.63$ & $1,459.33$ & $2,877.27$ & $44,244.73$ & $16,452.88$ \\
\hline fMSY (trip) & $34,411.03$ & $23,574.30$ & $19,353.34$ & $23,574.30$ & $32,820.73$ & $27,807.77$ \\
\hline fMEY (trip) & $33,569.38$ & $22,822.86$ & $19,100.80$ & $22,822.86$ & $30,222.14$ & $26,326.78$ \\
\hline fOA (trip) & $67,138.77$ & $45,645.73$ & $38,201.60$ & $45,645.73$ & $60,444.29$ & $52,653.56$ \\
\hline f Actual (trip) & $33,500.74$ & $29,893.99$ & $16,906.67$ & $29,893.99$ & $21,635.01$ & $17,733.61$ \\
\hline h MSY (ton) & $6,811.85$ & $2,888.54$ & $7,510.04$ & $2,888.53$ & $36,193.80$ & $10,275.08$ \\
\hline h MEY (ton) & $6,641.16$ & $2,793.53$ & $7,410.76$ & $2,793.53$ & $33,101.26$ & $9,698.70$ \\
\hline$h O A$ (ton) & 650.13 & 510.02 & 386.87 & 356.55 & $10,555.04$ & $2,072.35$ \\
\hline h Actual (ton) & $2,100.06$ & $1,081.93$ & $2,124.82$ & 1081.93 & $2,489.36$ & 940.11 \\
\hline
\end{tabular}


Secara keseluruhan, hasil analisis menunjukkan bahwa kondisi pemanfaatan (biomassa, produksi, dan effort) pada rezim MEY hampir tidak jauh berbeda dengan rezim MSY. Hal ini dimungkinkan karena biaya rata-rata per unit upaya tangkap (average of cost per unit effort) jauh lebih kecil dibandingkan dengan pendapatan yang diperoleh dari nilai jual hasil tangkapan per ton (average of price per ton of biomassa). Kondisi ini dikarenakan hasil tangkapan nelayan pada masing-masing Zona DPI rata-rata dibeli seluruhnya oleh pengepul untuk selanjutnya dipasarkan langsung atau masuk ke perusahaan perikanan. Beberapa penelitian lain juga menunjukkan kondisi yang sama dimana pemanfaatan perikanan pada kondisi MEY tidak jauh berbeda dengan kondisi MSY seperti Akoit dan Nalle (2018); Muawanah et al. (2017); dan Utami et al. (2020). Namun pada penelitian ini, adanya trade off antara sekor perikanan dan penambangan dalam pemanfaatan wilayah pesisir memberikan gambaran kasus yang berbeda pada pengelolaan perikanan skala kecil pada umumnya.

Kondisi pemanfaatan perikanan pada Zona A secara aktual baik pelagis maupun demersal berada di bawah hasil tangkap maksimum lestari atau produksi lestari (Maximum Sustainable Yield) dan surplus pendapatan maksimum lestari atau ekonomi lestari (Maximum Economic Yield) (Gambar 1).

Pada perikanan pelagis Zona $\mathrm{A}$, hasil analisis menunjukkan effort aktual masih berada di bawah titik MSY namun mendekati titik MEY, dengan produksi aktual masih di bawah $h$ MSY dan $h M E Y$ yang artinya belum terjadi overfishing. Namun besarnya upaya penangkapan (effort) aktual pada pelagis yang hampir mencapai optimal pada kondisi $f M E Y$ dengan produksi yang rendah menandakan bahwa cost yang dikeluarkan pada effort tidak efisien lagi baik secara ekonomi maupun biologi.Upaya tangkap selama kurun waktu 5 tahun terakhir juga cenderung meningkat sedangkan produksi cenderung menurun. Tingginya biaya effort pada Zona A dikarenakan dominan nelayan semakin sulit mencari ikan target karena kualitas perairan yang menurun akibat kekeruhan yang meningkat disebabkan sisa buangan penambangan laut yang terbawa arus, sehingga fishing ground menjadi semakin jauh (yang sebelumnya 2 mil menjadi 4-5 mil). Kombinasi penyebab tersebut merupakan akibat terjadinya range collapse pada Zona A. Menurut Adrianto et al., (2014), range collapse merupakan pengurangan drastis wilayah atau ruang spasial ekosistem laut yang biasa dihuni oleh stok ikan tertentu, dimana sumber daya ikan yang mengalami range collapse akan semakin sulit ditangkap karena telah terjadi penyusutan secara spasial dari biomassa stok ikan yang bersangkutan. Range collapse pada Zona A bukan hanya karena aktivitas penambangan oleh perusahaan, tetapi juga oleh aktivitas tambang rakyat ( $\mathrm{TI}$ apung dan ponton) yang ada sebagai akibat ikutan dari keberadaan penambang perusahaan.

Perikanan demersal pada Zona A menunjukkan jumlah effort berada diatas optimal baik pada kondisi $f$ MSY maupun $f$ MEY yang berarti upaya penangkapan perikanan demersal sudah tidak efisien secara ekonomi atau dapat dikatakan menunjukkan gejala economic overfishing karena jumlah input yang digunakan cukup tinggi, sehingga menciptakan ketidakseimbangan antara input (effort) dan

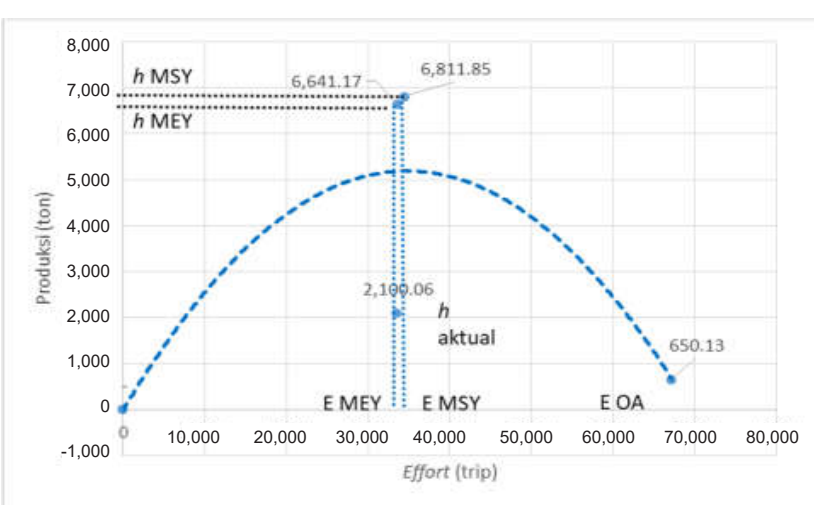

(a)

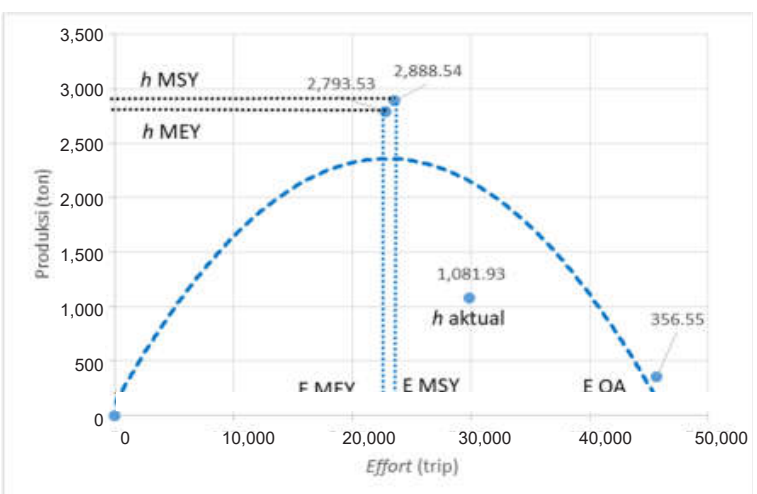

(b)

Gambar 1. Kurva Produksi MSY dan MEY Perikanan Pelagis Zona A (a) dan Demersal (b). Figure 1. Curve of MSY and MEY of Pelagic Fisheries in Zone A (a) and Demesal (b). 
output (produksi). Hal ini dikarenakan intensitas nelayan dalam mencari lokasi karang sebagai fishing ground semakin meningkat. Dalam 10 tahun terakhir luasan tutupan terumbu karang di wilayah timur pesisir Bangka semakin menurun (Nirwanda, Adi, \& Syari, 2017; Ilham \& Wahyu, 2016; Syari, 2016) sebagai akibat dari peningkatan sedimentasi, kekeruhan, dan ion logam dari sisa buangan penambangan laut (Anfaresi, Putri, Mulia, Alfisyahr, \& Muzayyannah, 2019; Nurtjahya, Franklin, Umroh, \& Agustina, 2017; Bidayani, 2014). Disatu sisi produksi pelagis dan demersal Zona A belum menunjukkan gejala overfishing karena masih berada di bawah optimal pada kondisi $h$ MSY dan $h$ MEY. Jika mengikuti basis perhitungan Total Allowable Cacth (TAC), rata-rata produksi perikanan pelagis maupun demersal Zona A adalah $42,67 \%$ atau masih berada dibawah TAC.

Pada Zona A1, kondisi aktual perikanan pelagis masih berada di bawah optimal baik pada kondisi MSY maupun MEY yang dilihat dari jumlah effort serta hasil tangkapan di bawah kondisi $f$ MSY dan $f$ MEY. Hal ini menandakan upaya penangkapan perikanan pelagis pada Zona A1 masih dapat dikatakan efisien walaupun produksi masih berada di bawah TAC serta belum terjadi overfishing. Namun pada perikanan demersal, effort aktual rata-rata berada di atas $f$ MSY dan $f M E Y$ walaupun produksi aktual masih di bawah $h$ MSY dan $h$ MEY. Kondisi ini menggambarkan bahwa perikanan demersal pada Zona A1 sudah tidak efisien secara ekonomi atau dapat dikatakan menunjukkan gejala economic overfishing, selain itu hasil tangkapan yang diperoleh hanya $26,74 \%$ TAC, jauh berada dibawah TAC (Gambar 2).
Perikanan pelagis pada Zona A1 tidak mengalami gangguan berarti dari akivitas penambangan laut dikarenakan IUP yang ada pada perairan 12 mil belum dilakukan aktivitas penambangan. Namun pada perikanan demersal Zona $\mathrm{A} 1$, dampak sisa buangan dari aktivitas penambangan di Zona $A$ atau pada perairan 4 mil menyebabkan penurunan kualitas perairan dan ekosistem terumbu karang akibat endapan sedimentasi yang terbawa arus.

Adapun pada Zona B, kondisi aktual perikanan pelagis dan demersal juga masih berada di bawah optimal pada kondisi MSY dan MEY baik dari jumlah effort maupun hasil tangkapan. Namun jumlah hasil tangkapan pada kondisi aktual jauh dibawah kondisi optimal baik $h$ MSY maupun $h M E Y$, yang menandakan bahwa effort bagan tancap kurang efisien dalam menghasilkan produksi perikanan pelagis dan demersal dikarenakan cost yang sangat tinggi. Kondisi ini juga menunjukkan adanya gejala economic overfishing pada Zona B sehingga kondisi perikanan pelagis dan demersal Zona B jauh di bawah efisien. Hasil tangkapan yang diperoleh masih jauh berada di bawah TAC atau di bawah 15\% TAC (Gambar 3).

Hasil analisis pada ketiga zona DPI menunjukkan status pemanfaatan yang berbedabeda. Zona A sebagai wilayah DPI yang terkena dampak langsung aktivitas IUP menunjukkan kondisi pemanfaatan yang paling rendah dibandingkan wilayah DPI lain yang tidak terkena dampak IUP. Hal ini diakibatkan oleh eskalasi pertambangan baik perusahaan skala besar maupun kecil (TI apung dan ponton) yang sejak

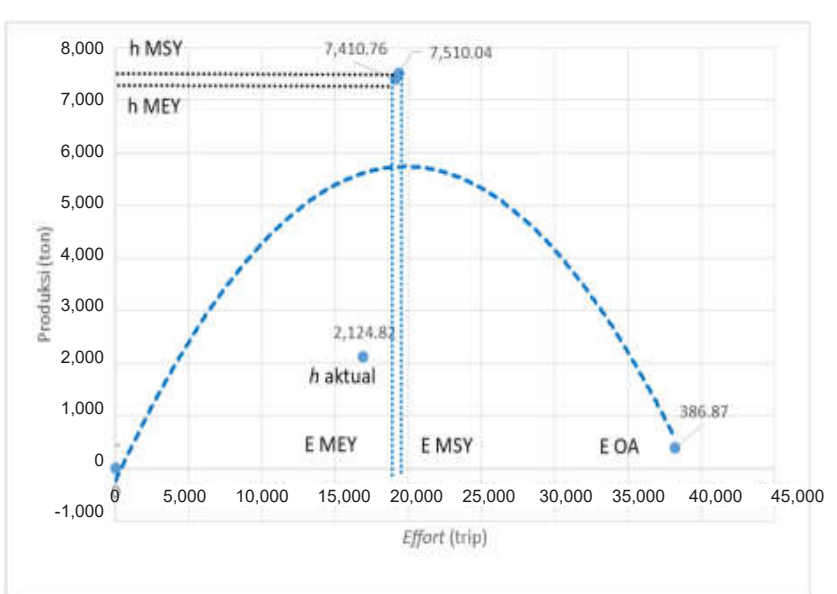

(a)

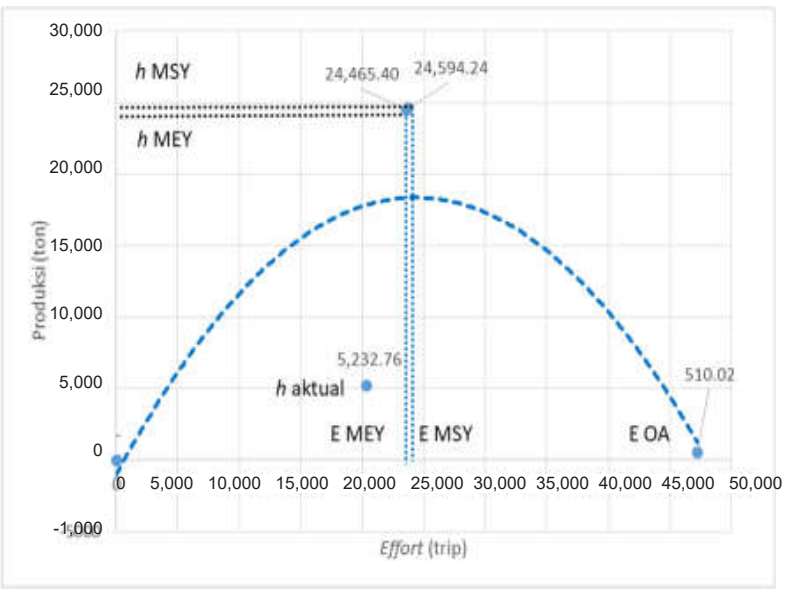

(b)

Gambar 2. Kurva MSY dan MEY Perikanan Pelagis Zona A1 (a) dan Demersal (b). Figure 2. Curve of MSY and MEY of Pelagic Fisheries in Zone A1 (a) and Demesal (b). 


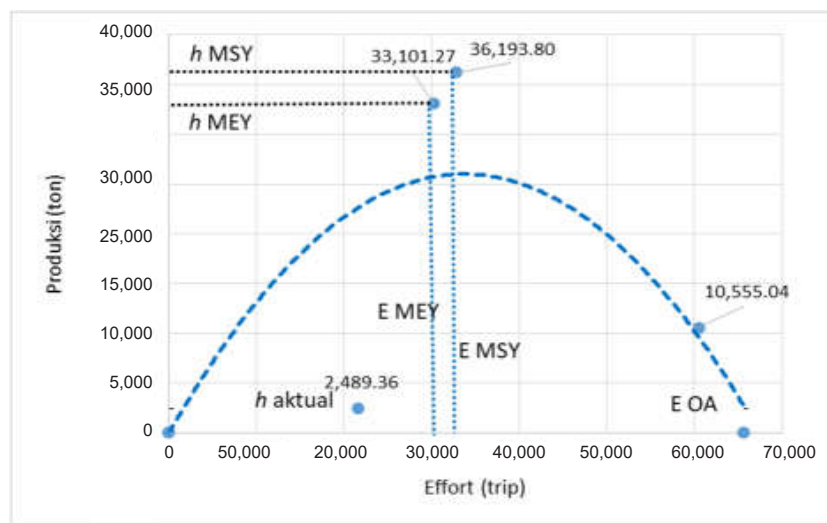

(a)

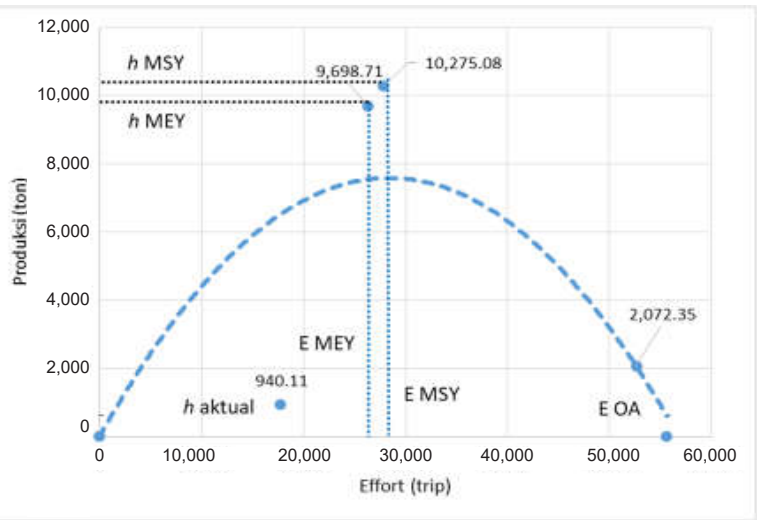

(b)

Gambar 3. Kurva MSY dan MEY Perikanan Pelagis Zona B (a) dan Demersal (b).

Figure 3. Curve of MSY and MEY of Pelagic Fisheries in Zone B (a) and Demesal (b).

lama telah menyebabkan dampak negatif terhadap ekologi maupun sosial, terutama pada nelayan jaring dan musiman dimana sekitar $86 \%$ nelayan tersebut menangkap ikan lebih sedikit (Rosyida \& Sasaoka, 2018). Aktifitas penambangan timah laut juga memberikan dampak negatif terhadap kelangsungan mata pencaharian nelayan setempat akibat jumlah dan jenis hasil tangkapan yang berkurang yang berujung pada pendapatan yang tidak menentu (Sulista et al., 2019; Helmi \& Satria, 2012).

Selama kurun waktu 5 tahun, pada Zona A terjadi penurunan effort yang mencapai $30 \%$ baik pelagis maupun demersal dengan produksi yang cenderung menurun. Menurut Bidayani (2013), penurunan pendapatan nelayan dapat terjadi karena kondisi perairan yang tidak optimal bagi kehidupan biota air akibat pencemaran oleh aktivitas pertambangan yang dilakukan di laut. Pencemaran aktivitas pertambangan berupa substrat sisa pencucian timah telah menyebabkan penurunan kualitas air terutama suhu, salinitas, kecerahan, dan kecepatan arus yang kurang optimal bagi pertumbuhan terumbu karang sebagai tempat hidup ikan (Febrianto, Baskoro, Simbolon, \& Haluan, 2015; M. Siringoringo \& Aryono Hadi, 2013; Oktariza, Wiryawan, Baskoro, Kurnia, \& Wisudo, 2016; Sari, Rosalina, \& Adi, 2017; Yunianto, 2009). Hal ini juga dapat terjadi pada produksi hasil tangkap. Terlihat bahwa perikanan demersal yang paling banyak mengalami kondisi inefisiensi ekonomi terutama pada Zona A dan A1 yang masih berdekatan dengan wilayah IUP.

Pada wilayah perairan yang belum terdapat aktivitas penambangan (Zona A1) atau tidak terdapat IUP laut (Zona B), pemanfaatan perikanan pelagis maupun demersal dapat dikatakan belum maksimal dikarenakan effort yang masih cenderung besar untuk hasil tangkap yang tidak terlalu besar. Hal ini dikarenakan nelayan pada Zona A1 maupun Zona B seringkali melaut lebih jauh daripada biasanya untuk memperoleh hasil tangkapan yang lebih banyak, begitu juga dengan bagan tancap yang didirikan pada perairan lebih dari 12 mil bahkan mencapai perairan 24 mil dalam upaya meningkatkan hasil tangkapan. Memperbesar upaya tangkap (effort) ini justru menimbulkan inefisien ekonomi pada usaha penangkapan, yang dapat berujung pada menurunnya pendapatan dan kesejahteraan nelayan itu sendiri (Fauzi, 2010; Zulbainarni, 2016).

Pengelolaan perikanan pada tiga zona berdasarkan analisis bioekonomi menunjukkan bahwa pada Zona A, perikanan pelagis menunjukkan gejala economical overfishing, sedangkan perikanan demersal sudah berada pada kondisi economical overfishing. Pada Zona A1, perikanan pelagis masih underfishing, sedangkan perikanan demersal menunjukkan kondisi economical overfishing. Perikanan pelagis dan demersal pada Zona A dan A1 dapat dikatakan belum efisien karena produksi rata-rata tidak mencapai $50 \%$ TAC. Adapun perikanan pelagis maupun demersal Zona B berada pada kondisi underfishing dan jauh dibawah efisien karena produksi rata-rata berada jauh dibawah TAC atau hanya berkisar $15 \%$ dari TAC. Wilayah DPI yang berdampingan langsung dengan IUP menunjukkan kondisi pemanfaatan yang tidak economic benefit atau tidak memberikan manfaat ekonomi yang positif karena effort yang diberikan berlebih. Namun DPI yang tidak berdampingan langsung dengan 
wilayah IUP, juga tidak memberikan manfaat ekonomi yang tinggi dikarenakan lokasi DPI yang sangat jauh sehingga cost yang dikeluarkan sangat besar.

\section{SINTESA KEBIJAKAN}

Wilayah DPI yang berdampingan langsung dengan IUP menunjukkan kondisi pemanfaatan yang tidak economic benefit atau tidak memberikan manfaat ekonomi yang positif karena effort yang diberikan berlebih. Namun DPI yang tidak berdampingan langsung dengan wilayah IUP, juga tidak memberikan manfaat ekonomi yang tinggi dikarenakan lokasi DPI yang sangat jauh sehingga cost yang dikeluarkan sangat besar. Input yang dibutuhkan baik pada wilayah DPI dengan IUP atau tidak, tetap akan lebih besar dikarenakan aktivitas melaut akan lebih lama dan jauh. Pada kondisi pengelolaan perikanan di wilayah pesisir Kabupaten Bangka, pengelolaan input merupakan komponen utama yang perlu dilakukan pengaturan, baik pengaturan kapasitas armada tangkap ataupun musim penangkapan. Namun permasalahan utama dalam pengelolaan perikanan di Kabupaten Bangka adalah pemanfaatan wilayah pesisir yang muti-sektor (perikanan, penambangan, pariwisata) yang menyebabkan penurunan kualitas perairan dan berujung pada penurunan produkivitas perikanan. Revitalisasi ekosistem pesisir merupakan upaya penting dalam menjaga keberlangsungan sumber daya ikan yang ada di wilayah pesisir Kabupaten Bangka.

\section{IMPLIKASI KEBIJAKAN}

Berdasarkan kondisi perikanan pelagis dan demersal pada masing-masing zona DPI, perlu dilakukan pengelolaan lebih lanjut agar pemanfaatan perikanan baik pelagis ataupun demersal dapat berkelanjutan baik secara ekologi maupun ekonomi. Opsi pengelolaan perikanan pada wilayah perairan yang berdampingan dengan IUP laut terutama dilakukan pada pengelolaan input, yaitu effort. Beberapa opsi diantaranya adalah: peningkatan kapasitas armada tangkap sampai dengan rata-rata $15 \mathrm{PK}$ dalam upaya mengatasi range collapse terutama pada wilayah DPI yang berdampingan langsung dengan IUP. Pemberlakukan pembatasan effort juga dapat dilakukan pada musim-musim paceklik. Pada Zona $B$, pengaturan upaya tangkap pada bagan tancap dengan memaksimalkan jumlah nelayan dalam satu armada tangkap sehingga dapat mengurangi cost yang dikeluarkan. Selain itu, pengelolaan perikanan juga harus disertai dengan pengelolaan sistem ekologi atau ekosistem. Pelestarian bersama ekosistem pesisir terutama terumbu karang antara pihak penambang yang memiliki IUP dengan nelayan lokal dapat dilakukan melalui program Corporate Social Responsibility (CSR) agar eksistensi habitat terumbu karang dapat terjaga selain juga dapat mengurangi konflik dengan para nelayan lokal.

\section{UCAPAN TERIMA KASIH}

Tulisan ini merupakan bagian dari tesis pada program studi Pengelolaan Sumber daya Pesisir dan Lautan, Sekolah Pascasarjana, Institut Pertanian Bogor. Untuk itu, penulis mengucapkan terima kasih kepada Pemerintah Provinsi Kepulauan Bangka Belitung melalui BKPSDM Provinsi Kepulauan Bangka Belitung atas beasiswa tugas belajar yang telah diberikan dan Bappeda sebagai instansi yang menaungi penulis.

\section{PERNYATAAN KONTRIBUSI PENULIS}

Kontributor dalam karya tulis ilmiah ini adalah Yeyen Mardyani, penulis pertama sebagai kontributor utama dan Rahmat Kurnia serta Luky Adrianto sebagai penulis kedua dan ketiga sebagai kontributor anggota yang sudah disepakati bersama-sama untuk diketahui semua pihak yang berkepentingan.

\section{DAFTAR PUSTAKA}

Adrianto, L. (2006). PengantarPenilaian Ekonomi Sumber daya Pesisir dan Laut. Bogor: PKSPL-IPB.

Adrianto L, Habibi A, Fahrudin A, Azizy A, Susanto HA, Musthofa I, Kamal M, Wisudo SH, Wardiatno Y, Raharjo P. et al. (2014). Modul Indikator Untuk Pengelolaan Perikanan Dengan Pendekatan Ekosistem. Jakarta (ID). Direktorat Sumber Daya Ikan Kementerian Kelautan dan Perikanan Republik Indonesia

Akoit, M. Y., \& Nalle, M. (2018). Pengelolaan Sumber daya Perikanan Berkelanjutan Di Kabupaten Timor Tengah Utara Berbasis Pendekatan Bioekonomi. Jurnal Agribisnis Indonesia, 6(2), 85. https://doi.org/10.29244/jai.2018.6.2.85-108

Alwi, I. (2012). Kriteria Empirik Dalam Menentukan Ukuran Sampel. Formatif: Jurnal IImiah Pendidikan MIPA, 2(2), 140-148.

Anfaresi, S. L. N., Putri, I. U., Mulia, R. A., Alfisyahr, F. A. N., \& Muzayyannah, N. (2019). Bangka's Tin Sea Sand-Fe3O4 as A Removal of Heavy Metals in By-Product of Tin Ore Processing Shofi. In 
Advances in Engineering Research (International Conference on Maritime and Archipelago (ICoMA 2018)) (Vol. 167, pp. 79-84). Atlantis Press. doi:10.1007/s40242-018-8213-z

Atmaja, S. B., \& Nugroho, D. (2017). Upaya-Upaya Pengelolaan Sumber Daya Ikan Yang Berkelanjutan Di Indonesia. Jurnal Kebijakan Perikanan Indonesia, 3(2), 101. doi:10.15578/ jkpi.3.2.2011.101-113

Azevedo, E. Z. D. de, Dantas, D. V., \& Daura-Jorge, F. G. (2020). Risk tolerance and control perception in a game-theoretic bioeconomic model for small-scale fisheries. Royal Society Open Science, 7(7), 200621. doi:10.1098/rsos.200621

Badan Pusat Statistik. (2018). Kabupaten Bangka Dalam Angka 2018. Pangkalpinang, ID: BPS Kabupaten Bangka.

Béné, C., Hersoug, B., \& Allison, E. H. (2010). Not by Rent Alone : Analysing the Pro-Poor Functions of Small-Scale Fisheries in Developing Countries. Development Policy Review, 28(3), 325-358.

Bidayani, E. (2014). Ekonomi Sumber daya Pesisir yang Tercemar. Malang, ID: Universitas Brawijaya (UB) Press.

Bidayani, E., \& Kurniawan. (2020a). Resolusi Konflik Pemanfaatan Sumber daya Pesisir antara Nelayan dengan Penambang Timah Inkonvensional. Society, 8(1), 14-24.

Bidayani, E., \& Kurniawan, K. (2020b). Conflict Resolution in Coastal Resource Utilization among Fishermen and Unconventional Tin Miners. Society, 8(1), 13-22. doi:10.33019/society.v8i1.139

Bidayani, E., Kurniawan, K., Anggeraini, L., \& Aisyah, S. (2020). Utilization Conflict Analysis of Fisheries Resources with Tin Mining and Marine Tourism in East Coast of Bangka Island. In Proceedings of the 13th International Interdisciplinary Studies Seminar, IISS 2019. Malang, Indonesia: European Alliance for Innovation (EAI). doi:10.4108/eai.2310-2019.2293011

Charles, AT. (2001). Sustainable Fishery System. Oxford, UK: Blackwell Science.

Dahuri R, Rais J, Ginting SP, Sitepu. 2001. Pengelolaan Sumber daya Wilayah Pesisir Dan Lautan Secara Terpadu. Jakarta Timur, ID: PT Balai Pustaka (Persero).

Dinas Kelautan dan Perikanan (DKP) Provinsi Kepulauan Bangka Belitung. (2019). Statistik Perikanan Provinsi Kepulauan Bangka Belitung 2018. Pangkalpinang, ID: DKP Provinsi Kepulauan Bangka Belitung.

Dinas Kelautan dan Perikanan (DKP) Kabupaten Bangka. (2018). Laporan Sensus Perikanan Kabupaten Bangka 2018. Pangkalpinang, ID: DKP Kabupaten Bangka.
Dinas Energi dan Sumber daya Mineral (ESDM) Provinsi Kepulauan Bangka Belitung. 2018. Rekapitulasi IUP di Perairan Provinsi Kepulauan Bangka Belitung. Pangkalpinang,ID: ESDM Provinsi Kepulauan Bangka Belitung.

Diop, B., Sanz, N., Duplan, Y. J. J., Guene, E. H. M., Blanchard, F., Pereau, J. C., \& Doyen, L. (2018). Maximum Economic Yield Fishery Management in the Face of Global Warming. Ecological Economics, 154(June 2018), 52-61. doi:10.1016/j.ecolecon.2018.07.027

Fauzi, A. (2000). Mencari Penerimaan Negara melalui Fishing Fee. Jakarta, ID: Media Indonesia.

Fauzi, A., \& Anna, S. (2005). Pemodelan Sumber daya Perikanan dan Kelautan untuk Analisis Kebijakan. Jakarta, ID: PT Gramedia Pustaka Utama.

Febrianto, A., Baskoro, M. S., Simbolon, D., \& Haluan, J. (2015). The Impact of Tin Mining Activities on Squid ( Uroteuthis chinensis ) Fishing Ground In South Bangka. International Journal of Sciences: Basic and Applied Research (IJSBAR), 23(1), 283-293.

Hesselgrave, T., Kruse, S., \& Sheeran, K. A. (2011). The Hidden Cost of Overfishing to Commercial Fishermen: A 2009 Snapshot of Lost Revenues. Portland, OR: Ecotrust.

Ibrahim, I., Haryadi, D., \& Wahyudin, N. (2018). From Charm To Sorrow: the Dark Portrait of Tin Mining in Bangka Belitung, Indonesia. PEOPLE: International Journal of Social Sciences, 4(1), 360-382. doi:10.20319/pijss.2018.41.360382

Ilham, A. , Wahyu., A .U. (2016). Pola Sebaran Karang Lunak (Soft Coral) terhadap Kedalaman yang Berbeda di Pantai Tuun Aban, Tanjung Pesona,dan Rebo, 10(2015), 223-226.

Kementerian Kelautan dan Perikanan Republik Indonesia. (2017). Keputusan Menteri Kelautan dan Perikanan Nomor: 50/KEPMEN-KP/2017 tentang Estimasi Potensi Sumber Daya Ikan di Wilayah Pengelolaan Perikanan Negara Republik Indonesia.

(2016). Peraturan Menteri Kelautan dan Perikanan Nomor 71 Tahun 2016 tentang Jalur Penangkapan Ikan Dan Penempatan Alat Penangkapan Ikan di Wilayah Pengelolaan Perikanan Negara Republik Indonesia.

Kim, T. goun. (2009). Efficient management of marine resources in conflict: An empirical study of marine sand mining, Korea. Journal of Environmental Management, 91(1), 78-86. doi:10.1016/j. jenvman.2009.07.006

M. Siringoringo, R., \& Aryono Hadi, T. (2013). The Condition and Distribution of Stony Corals (Scleractinia corals) in Bangka Water. IImu Dan Teknologi Kelautan, 5(2), 273-285. doi:10.29244/ jitkt.v5i2.7557 
Manik, J. D. N. (2018). Kebijakan Pertambangan Laut Timah Yang Berdampak Pada Lingkungan. Journal of Chemical Information and Modeling, 2(1), 89-99. doi:10.1017/CBO9781107415324.004

Mardyani, Y., Kurnia, R., \& Adrianto, L. (2019). Status Pengelolaan Perikanan Skala Kecil Berbasis Zonasi di Wilayah Perairan Kabupaten Bangka. Jurnal Kebijakan Perikanan Indonesia, 11(November), 125-137.

Mota, R. P. (2020). Fishery harvest control rules from bioeconomic optimization. Marine Policy. doi:10.1016/j.marpol.2020.103865

Muawanah, U., Huda, H. M., Koeshendrajana, S., Nugroho, D., Anna, Z., \& Ghofar, A. (2017). Keberlanjutan Perikanan Rajungan Indonesia:Pendekatan Model Bioekonomi. Jurnal Kebijakan Perikanan Indonesia, 9(2), 71-83.

Nirwanda, S., Adi, W., \& Syari, I. A. (2017). Inventarisasi Penyakit Karang Di Perairan Turun Aban Kabupaten Bangka. Sumber daya Perairan, 11(1), 18-25.

Nurtjahya, E., \& Agustina, F. (2015). Managing the socio-economic impact of tin mining on Bangka Island, Indonesia - preparation for closure. The 10th International Conference on Mine Closure, (June), 1-10.

Nurtjahya, E., Franklin, J., Umroh, \& Agustina, F. (2017). The Impact of tin mining in Bangka Belitung and its reclamation studies. MATEC Web of Conferences, 101, 1-6. https://doi.org/10.1051/ matecconf/201710104010

Oktariza, W., Wiryawan, B., Baskoro, M. S., Kurnia, R., \& Wisudo, S. H. (2016). Bio-Economic Model of Squid Fisheries in The Waters of Bangka Regency, Bangka Belitung Islands Province. Marine Fisheries: Journal of Marine Fisheries Technology and Management, 7(1), 97. doi:10.29244/jmf.7.1.97-107

Pauly, D. (1987). Theory and practice of overfishing: a Southeast Asian perspective. In Papers Presented at the Symposium on the Exploitation and Management of Marine Fishery Resources in Southeast Asia, 22nd Session, Indo-Pacific Fishery Commission, Darwin, Australia.

Purcell, S. W., \& Pomeroy, R. S. (2015). Driving small-scale fisheries in developing countries. Frontier in Marine Science, 2(June), 1-7. doi:10.3389/fmars.2015.00044

Puspita Sari, S., Rosalina, D., \& Adi, W. (2017). Bioakumulasi timbal $(\mathrm{Pb})$ dan cadmium $(\mathrm{Cd})$ pada lamun Cymodocea serrulata di Perairan Bangka Selatan. Depik (Jurnal IImu-IImu Perairan, Pesisir, Dan Perikanan), 6(2), 128-137. doi:10.13170/ depik.6.2.7783
Ramadona, T., Rengi, P., Warningsih, T., Septya, F., Ngesti, S. M., \& Purnomo, A. (2020). Does Capture Fisheries in the Vicinity of Tin Mining Area Sustainable?: A case study in Bangka Island, Indonesia. IOP Conference Series: Earth and Environmental Science, 430(1). doi:10.1088/1755-1315/430/1/012015

Rosyida, I., \& Sasaoka, M. (2018). Local political dynamics of coastal and marine resource governance: A case study of tin-mining at a coastal community in Indonesia. Environmental Development, 26, 12-22. doi:10.1016/j.envdev.2018.03.003

Smith, I. R. (1981). Improving fishing incomes when resources are overfished. In Marine Policy (pp. 17-22). IPC Business Press.

Sulaiman, A., Zulkarnain, I., \& Fakhrurrozi, Y. (2015). Model Kebijakan Pengelolaan Sumber daya Kelautan dalam Persfektif Resolusi Konflik (Studi Kasus Nelayan Teluk Limau Bangka Barat Provnsi Kepulauan Bangka Belitung). Jurnal Bumi Lestari, 15(2), 92-102.

Sulista, S., Ibrahim, I., \& Pratama, S. (2019). Accommodation, Resistance and Divided Community: Study of the Dynamics of Offshore Tin Mining Conflict Between the Fishermen of the Coastal Area and Companies in Bangka Island. PEOPLE: International Journal of Social Sciences, 5(3), 275-296. doi:10.20319/ pijss.2019.53.275296

Syari, I. A. (2016). Kondisi Terumbu Karangdi Perairan Rebo Sungailiat Bangka Akibat Pertambangan Timah. Jurnal Sumber daya Perairan, 10(1), 13-20.

Utami, P. B., Kusumastanto, T., Zulbainarni, N., \& Ayunda, N. (2020). Analisis Bioekonomi Perikanan Tuna Sirip Kuning Di Larantuka, Kabupaten Flores Timur, Indonesia. Jurnal Kebijakan Sosial Ekonomi Kelautan Dan Perikanan, 10(1), 1. doi:10.15578/jksekp.v10i1.7766

Yunianto, B. (2009). Kajian problema pertambangan timah di Propinsi Kepulauan Bangka Belitung sebagai masukan kebijakan pertimahan nasional. Jurnal Teknologi Mineral Dan Batubara, 5(3), 97-113.

Zulbainarni, N. (2016). Teori dan Praktik Pemodelan Bioekonomi dalam Pengelolaan Perikanan Tangkap Edisi Revisi. Bogor, ID: PT Penerbit IPB Press. 